\title{
AUTOMATIC CONTROL SYSTEMS
}

UDC 681.5.011 (045)

DOI: $10.18372 / 1990-5548.56 .12930$

${ }^{1}$ A. K. Ablesimov,

${ }^{2}$ L. V. Pohribniak

\section{STATISTICAL METHODS OF ESTIMATING THE RESPONSE OF AUTOMATIC SYSTEM ON CONTROL COMMANDS}

\author{
${ }^{1,2}$ Aviation Computer-Integrated Complexes Department, National Aviation University, Kyiv, Ukraine
} E-mails: ${ }^{1}$ alexander.ablesimov@gmail.com, ${ }^{2}$ liudmila.pohribniak@gmail.com

\begin{abstract}
It was established the impossibility to estimate the reaction of automatic control systems on typical signals and also to disallowed only take into account the quality rates. The results of theoretical and experimental research showed, that control signals are random. For the purpose of estimating influences of these signals, it is necessary to use statistical methods to evaluate the response of the automatic control system on operator commands. It is considered the method of estimating the accuracy of automatic control systems that operates in modes of stable guidance at random disturbing influences and control signals.
\end{abstract}

Index Terms-Transfer function; control object; damping; stiffness; disturbing moment; a control signal; spectral density; amplitude and phase frequency response dispersion; mean square error; characteristic polynomial.

\section{INTRODUCTION}

During the estimation of the control quality and choosing the regions of exploitation regulations of the automatic control systems (ACS) it is disallowed only to take into account the quality rates.

That is not enough to know the time of the transient process, oscillation and overregulation, which characterizes the reaction of the system only on previously chosen custom external action.

To ensure the quality of control of ACS, one must also take into account the effect of random stationary processes, such as processes of amplitude, speed and acceleration of the control object, and the action of external disturbing influences.

\section{PROBLEM STATEMENT}

Control signals, formed by the operator at the input of ACS, during targeting a control object or tracking the objects of observation, are also random functions of time. It is stipulated by the randomicity of the relative movement of movable base and the object of observation. In result, the operator creates a random control signal at the input of system in order to offset errors of aiming.

Thus, it is necessary to use statistical methods to evaluate the response of the automatic control system on operator commands.

\section{PROBlem SOLUTION}

The analysis of the ACS shows that the systems which are different by the construction have the same structure and the same transfer functions. This makes us to observe the approach to their analysis on the generalized structural scheme [1], which is shown in Fig. 1.

The following designations are accepted in structural scheme: $W_{\mathrm{co}}(s)=\frac{k_{\mathrm{co}}}{\left(T_{\mathrm{co}} s+1\right)}$ is the transfer function of a control object; $G=k_{\mathrm{ds}} k_{\text {reg }}$ is the stiffness of a system which is considered by the gain coefficient of the deflection sensor $k_{\mathrm{ds}}$ and the regulator $k_{\mathrm{reg}}$; $D=k_{\mathrm{sds}} k_{\mathrm{reg}}$ is the damping of a system which is considered by the gain coefficient of the speed deflection sensor $k_{\mathrm{sds}}$ and regulator $k_{\mathrm{reg}} ; M_{y \Sigma}(s)$ is the total disturbing moment which impacts on the control object; $M_{S}$ is the moment of stabilization; $R(s)$ is the control signal which is formed by an operator.

The spectral densities of the moments of forces, which are formed by an operator at the input of the deflection sensor, are shown in Fig. 2. Characteristics are measured during the middlecross-country motion. The spectral densities analysis shows that operator is able only to elaborate the most low-frequent part of external disturbances since its pass band is limited by the frequency of $6 \mathrm{rad} / \mathrm{s}(1 \mathrm{~Hz})$.

Most effectively operator fulfills external disturbances, the frequency of which is less than $3 \mathrm{rad} / \mathrm{s}$ (less than $0.5 \mathrm{~Hz}$ ). Therefore, in real terms, the operator can compensate the deviations caused by goings of gyro angle sensor, low-frequency disturbances, caused by changes in azimuth movement of the object on the ground. The deviations, caused by high-frequency part of the spectrum of perturbations, the operator can not compensate physically. 


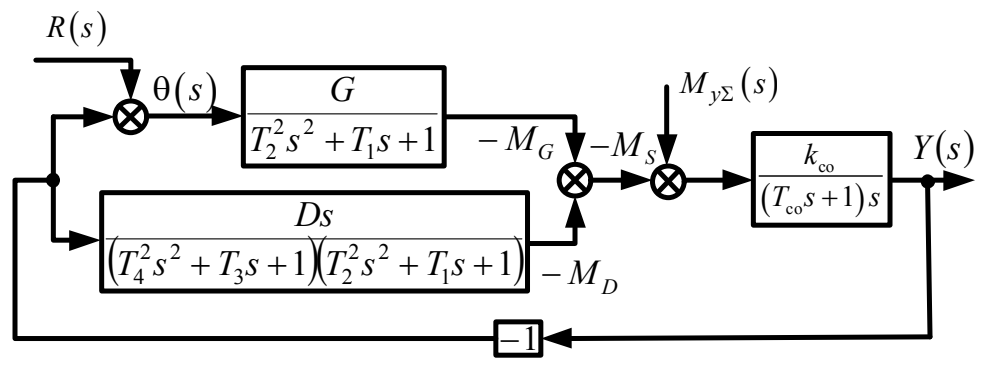

Fig. 1. The generalized structural scheme of the automatic control system

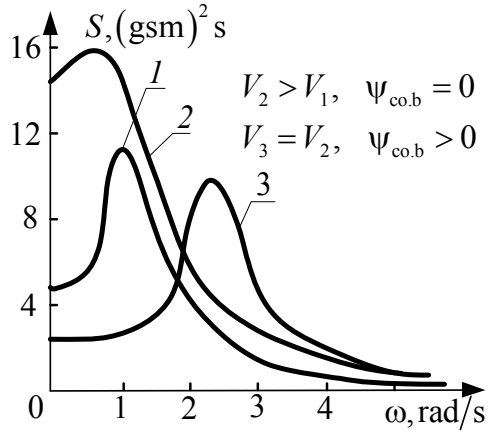

Fig. 2. The spectral densities of the moments of targeting, which are formed by an operator

From the theory of random processes and statistical dynamics it is known that the connection between the spectral density $S(\omega)$ of a random signal, acting on the input of the linear system and the spectral density $S_{\text {os }}(\omega)$ of the output signal is formed by the correlation:

$$
S_{\text {os }}(\omega)=S(\omega)|W(j \omega)|^{2},
$$

where $W(j \omega)$ is the amplitude-phase-frequency characteristic of the system regarding to observed input; $S(\omega)=\frac{2}{\pi} \int_{0}^{\infty} R(\tau) \cos \omega \tau d \tau$ is a spectral density of the input signal.

If the spectral density of the output signal $S_{\text {os }}(\omega)$ is known, it is possible to detect its dispersion

$$
D=\int_{0}^{\infty} S_{\mathrm{os}}(\omega) d \omega
$$

as well as corresponding to it mean-squared error (MSE), $\sigma=\sqrt{D}$, which is a criterion of the quality of the system upon addition to its input a random signal.

In case when the system has several input signals according to the principle of superposition the spectral density at the output of the system must be determined by taking into account each of the components

$$
\begin{aligned}
S_{\text {os } \Sigma}(\omega)=S_{1}(\omega)\left|W_{1}(j \omega)\right|^{2} & \\
& +S_{2}(\omega)\left|W_{2}(j \omega)\right|^{2}+\ldots .
\end{aligned}
$$

It should be noted, that the accuracy of the automatic control system is fully characterized by the quantity and nature of the variation of discrepancy error $\theta(t)=r(t)-y(t)$.

Thus, to evaluate the accuracy of ACS, which operates in mode of stabilized aiming, except disturbing moments $m_{y \sum}(t)$, must be taken into account the statistical characteristics $r(t)$ of the operator (Fig. 2).

Suppose that the probability characteristics of random control signals $r(t)$ and external disturbances $m_{y \sum}(t)$, are known.

Let us find according to Fig. 1, the transfer function of the discrepancy error

$$
\begin{aligned}
& W_{s}(s)=\frac{\theta(s)}{R(s)} \\
& =\frac{\left(T_{\mathrm{co}} s+1\right) s\left(T_{2}^{2} s^{2}+T_{1} s+1\right)\left(T_{4}^{2} s^{2}+T_{3} s+1\right)+k_{\mathrm{co}} D s}{A(s)} .
\end{aligned}
$$

Here $A(s)$ is the characteristic polynomial of the system:

$$
\begin{aligned}
A(s)= & a_{6} s^{6}+a_{5} s^{5}+a_{4} s^{4}+a_{3} s^{3} \\
& +\left(a_{2}+k_{\mathrm{co}} G T_{4}^{2}\right) s^{2}+k_{\mathrm{co}}\left(D_{\Sigma}+G T_{3}\right) s+k_{\mathrm{co}} G .
\end{aligned}
$$

The coefficients of the characteristic polynomial are determined by the time constants of the ACS elements and are equal

$$
\begin{aligned}
& a_{6}=T_{4}^{2} T_{2}^{2} T_{\mathrm{co}}, \\
& a_{5}=T_{4}^{2} T_{2}^{2}+T_{4}^{2} T_{1} T_{\mathrm{co}}+T_{3} T_{2}^{2} T_{\mathrm{co}}, \\
& a_{4}=T_{4}^{2} T_{1}+T_{4}^{2} T_{\mathrm{co}}+T_{3} T_{2}^{2}+T_{3} T_{1} T_{\mathrm{co}}+T_{2}^{2} T_{\mathrm{co}}, \\
& a_{3}=T_{4}^{2}+T_{3} T_{1}+T_{3} T_{\mathrm{co}}+T_{2}^{2}+T_{1} T_{\mathrm{co}}, \\
& a_{2}=T_{3}+T_{1}+T_{\mathrm{co}} .
\end{aligned}
$$

Let us give the expression (1) a view 


$$
W_{s}(s)=\frac{G(s)}{A(s)},
$$

where $G(s)$ is the characteristic polynomial of the open-loop system:

$$
\begin{aligned}
G(s)=a_{6} s^{6}+a_{5} s^{5} & +a_{4} s^{4} \\
& +a_{3} s^{3}+a_{2} s^{2}+k_{\mathrm{co}} D s .
\end{aligned}
$$

The transfer function of the error of external disturbance is defined as

$$
\begin{aligned}
W_{s m}(s)= & \frac{\theta(s)}{M_{y \Sigma}(s)} \\
& =\frac{k_{\text {co }}\left(T_{2}^{2} s^{2}+T_{1} s+1\right)\left(T_{4}^{2} s^{2}+T_{3} s+1\right)}{A(s)} .
\end{aligned}
$$

In accordance with the principle of superposition discrepancy error of the system is defined as

$$
\theta_{\Sigma}(s)=W_{s}(s) R(s)+W_{s m}(s) M_{y \Sigma}(s) .
$$

Taking into account the random nature of the control signal and disturbance, after substituting in (2) the values of the frequency transfer functions $W_{s}(j \omega), W_{s m}(j \omega)$ and spectral densities of control signal $S_{r}(\omega)$ and disturbance $S_{M y \Sigma}(\omega)$, we obtain an equation for calculating the spectral density of the total discrepancy error of the system

$$
\begin{aligned}
S_{\theta \Sigma}(\omega) & =\frac{|G(j \omega)|^{2}}{|A(j \omega)|^{2}} S_{r}(\omega) \\
& +\frac{k_{\mathrm{co}}^{2}\left|\left(1-T_{2}^{2} \omega^{2}+j T_{1} \omega\right)\left(1-T_{4}^{2} \omega^{2}+j T_{3} \omega\right)\right|^{2}}{|A(j \omega)|^{2}} S_{M y \Sigma}(\omega) .
\end{aligned}
$$

In determining the reaction of the automatic control system on the operator's control signals is necessary to consider the impact of operational adjustments on the formation of the amplitude-frequency characteristics of the system.

Figures 3 and 4 show a family of amplitude-phase frequency and amplitude-frequency characteristics of the ACS relative to the operator's signal. The characteristics obtained at constant stiffness and variable damping.

In the case of increasing stiffness the resonance peak of the curve shifts towards higher frequencies. Analysis of these characteristics shows that to ensure the required accuracy in a stabilized aiming mode requires an appropriate adjustment of system.

Thus, the technical conditions for operational adjustments of automatic control systems must be set in such a way that simultaneously provides high-quality tracking and maximum accuracy stabilization.

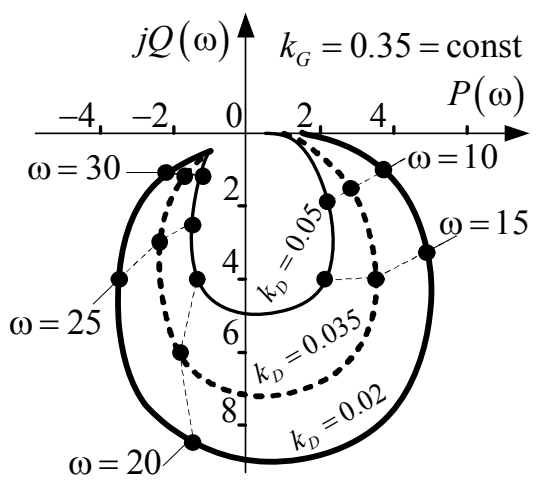

Fig. 3. Amplitude-phase frequency characteristics by the control channel

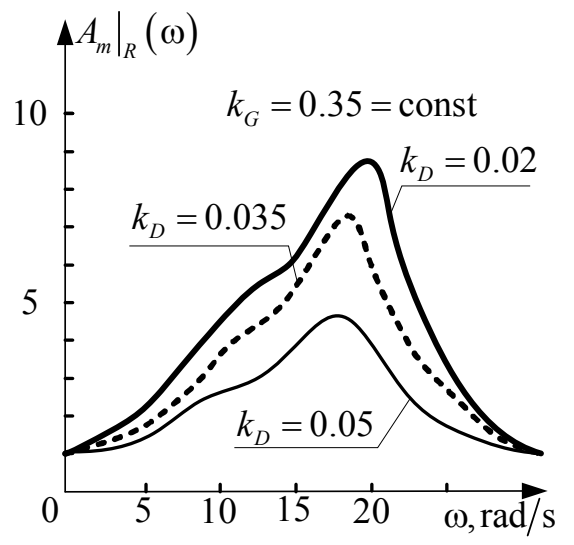

Fig. 4. Amplitude-frequency characteristics by the control channel

\section{CONCLUSION}

Availability of information on probability characteristics of the control signals of operator and disturbances allows the developer of automatic control systems to choose the parameters of the controller so as to ensure maximum difference of the peaks of the amplitude-phase-frequency characteristics of the systems and the spectral densities of the aforementioned signals. In this case, can be ensured maximum accuracy of the system in modes of stabilization and stabilized aiming.

\section{REFERENCES}

[1] O. K. Ablesimov, E. E. Alexandrov, and I. E. Alexandrova, Automatic control of moving objects and technological processes. Kharkov: NTU "KhPI", 2008, 443 p. (in Ukrainian).

[2] O. K. Ablesimov, Course of the theory of automatic control. Kyiv: Osvita Ukrainy. 2014, 270 p. (in Ukrainian).

Received January 11, 2018 
Ablesimov Aleksandr. Candidate of Science (Engineering). Professor.

Aviation Computer Integrated Complexes Department, National Aviation University, Kyiv, Ukraine.

Education: Military Academy of Armored Forces, Moscow, USSR, (1971).

Research interests: Automatic control systems.

Publications: 266.

E-mail: alexander.ablesimov@gmail.com

Pohribniak Liudmila. Student.

Aviation Computer-Integrated Complexes Department, National Aviation University, Kyiv, Ukraine.

Research interests: Automatic control systems.

Publications: 3 .

E-mail: liudmila.pohribniak@gmail.com

О. К. Аблесімов, Л. В. Погрібняк. Статичні методи оцінювання реакції автоматичної системи на команди контролю

Встановлено, неможливість оцінювати реакцію системи автоматичного керування лише на типові сигнали $\mathrm{i}$ обмежуватись лише показниками якості. Результати теоретичних і експериментальних досліджень показали, що керовані сигнали системи є випадковими. 3 метою оцінювання впливу цих керованих сигналів необхідно використовувати статичні методи оцінки реакції системи на команди оператора. В роботі розглянуто метод оцінювання точності систем автоматичного керування, який працює в режимах стійкого керування при випадкових зовнішніх впливах.

Ключові слова: датчик швидкості; частотна характеристика; коефіцієнт загасання; «одиничний» гіроскоп; амплітудна помилка; фазова помилка; хвильова діаграма; нормована характеристика; відносна частота.

Аблесімов Олександр Костянтинович. Кандидат технічних наук. Професор.

Кафедра авіаційних комп’ютерно-інтегрированних комплексів, Національный авіаційний університет, Київ, Україна.

Освіта: Військова академія бронетанкових військ, Москва, СРСР, (1971).

Направлення наукової діяльності: системи автоматичного керування.

Кількість публікацій: 266.

E-mail: alexander.ablesimov@gmail.com

Погрібняк Людмила Вікторівна. Студентка.

Кафедра авіаційних комп’ютерно-інтегрованих комплексів, Національний авіаційний університет, Київ, Україна. Напрям наукової діяльності: системи автоматичного керування.

Кількість публікацій: 3.

E-mail: liudmila.pohribniak@gmail.com

А. К. Аблесимов, Л. В. Погребняк. Статические методы оценки реакции автоматической системы на команды управления

Установлена, невозможность оценивать реакцию системы автоматического управления только на типичные сигналы и ограничиваться лишь показателями качества. Результаты теоретических и экспериментальных исследований показали, что управляемые сигналы системы являются случайными. С целью оценки влияния этих управляемых сигналов необходимо использовать статические методы оценки реакции системы на команды оператора. В работе рассмотрен метод оценки точности систем автоматического управления, который работает в режимах устойчивого управления при случайных внешних воздействиях.

Ключевые слова: датчик скорости; частотная характеристика; коэффициент затухания;«единичный» гироскоп; амплитудная ошибка; фазовая ошибка; волновая диаграмма; нормированная характеристика; относительная частота..

Аблесимов Александр Константинович. Кандидат технических наук. Профессор.

Кафедра авиационных компьютерно-интегрированных комплексов, Национальный авиационный университет, Киев, Украина.

Образование: Военная академия бронетанковых войск, Москва, СССР, (1971).

Направление научной деятельности: системы автоматического управления.

Количество публикаций: 266.

E-mail: alexander.ablesimov@gmail.com

Погребняк Людмила Викторовна. Студентка.

Кафедра авиационных компьютерно-интегрированных комплексов, Национальный авиационный университет, Киев, Украина.

Направление научной деятельности: системы автоматического управления.

Количество публикаций: 3 .

E-mail:_liudmila.pohribniak@gmail.com 